\title{
The Influence of Religious Figures in Adult's Halal Cosmetic Buying Behavior
}

\section{Pengaruh Tokoh Agama terhadap Perilaku Pembelian Kosmetik Halal Orang Dewasa}

\author{
Meike Kurniawati \\ Universitas Tarumanagara, Jakarta, Indonesia
}

\begin{abstract}
ARTICLE INFO
ABSTRACT

Article history:

DOI:

$\underline{10.30595 / p s s h . v 2 i .123}$

Submitted: July 30, 2021

Reference groups are considered a social influence in consumer purchasing. Person or groups that consumers will look to make a purchase decision. The reference group has three types of influences, such as informative comparative and normative influences, that can become a power to influence buying behavior and brand selection-many kinds of reference groups. Religious figures are one of them. This research aims to determine whether religious figures influence the purchasing behavior of halal cosmetics. Consumer perception of religious figures' influence on halal cosmetic buying behavior was examined

Accepted: Aug 19, 2021 using 200 halal cosmetic users. Women, 20 - 40 years old, the user of Halal Cosmetic. The data is processed using simple regression. Regression test show that $r=0.421$ and sig $(\mathrm{p})=0.000 ; \mathrm{p}<0.05$. The value of $\mathrm{R}=0.421, \mathrm{R}^{2}=0.177$ indicates that the religious

Published: Sept 24, 2021 figures' influence on buying halal products is $17.7 \%$, while other factors influence the remaining $82.3 \%$.
\end{abstract}

Keywords:

This work is licensed under a Creative Commons Attribution 4.0 International License.

Halal cosmetic, reference group religious figures, purchasing behavior,

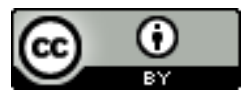
adolescence

\section{Corresponding Author:}

Meike Kurniawati

Universitas Tarumanagara, Jakarta Indonesia

Email: meikek@fpsi.untar.ac.id

\section{INTRODUCTION}

In recent years, the demand for halal products has brought a significant increase worldwide. If the previously halal product market was considered limited and not profitable, halal products have become popular. For several countries, halal products have become a commodity that increases foreign exchange (Endang, 2014).

One of the halal products that are currently developing into a positive trend is halal cosmetic products. Halal cosmetics are presently on the rise in the Asia Pacific (www.Muslim.co.id 2016), including Indonesia. The potential market for halal cosmetics is estimated at \$2.7 trillion globally (World Halal Forum, 2013).

As a country with more than 200 million $(80.2 \%)$ population adheres to Islam, it can be said that Indonesia is a potential market for halal products. Indonesia, as a country with the largest Muslim population in the world, coupled with a positive direction for the development of halal cosmetics, certainly makes Indonesia a potential market for halal cosmetic products. One of the halal products that are currently developing into a positive trend is halal cosmetic products.

The halal cosmetics industries are gaining the world's attention because Muslims feel peace by consuming halal products in every part of their lives (Ali et al., 2016). The 'halalness' knowledge of the products is essential during decision making (to accept or reject) a product (Ireland, John \& Rajabzadeh, 2011). Besides meat-based products, Halal principles also govern commodities, such as finance, banking, insurance, cosmetics, pharmaceuticals, etc.

One of the factors that influence purchasing decisions is the reference group. Sumarwan (in Jayawijaya, Arifin \& Sunarti, 2017) defines the reference group as an individual or group that significantly influences a person's behavior. The reference group influences buying interest and the use of certain goods or services, also brand selection. Reference groups often use by marketers as part of marketing communication. Choosing the correct type 
of reference group in marketing communication is essential because the right choices will increase sales. Vice Versa.

References groups are considered a social influence in consumer purchasing. Person or groups that consumers will look to make a purchase decision. Previous research has shown that individuals often make consumption choices due to their various reference groups' influence (Escalas, Jennifer \& Bettman, 2015). From the phenomenon \& previous research mentioned above, it's attractive to know how religious figures influence halal cosmetic buying in adult consumers. Religious figures choose because Halal is related to religion.

\section{THEORITICAL FRAMEWORK}

Buying behavior on consumers is influenced by several factors, including cultural, social, personal, and psychological factors. Social factors include the influence of family, reference group, social class, culture, and subculture.

Purchasing decisions are a stage where consumers buy (Kotler \& Amstrong, 2016). Purchasing decisions process combines knowledge to evaluate two or more alternative behaviors and chooses one of them (Setiadi, 2015). Purchasing decisions are made to fulfill and satisfy wants and needs (Awantary, 2014). (Sangaji, 2013) states that purchasing decisions are the choice from two or more alternatives. In line with Sangaji (2013), (Schiffman, L. G., Kanuk, L. L., \& Hansen, 2012) state that the buying decision is to choose one of two or more choices to buy. Consumer purchasing behavior is described as all the psychological and physical activities individuals perform to satisfy their needs and wants (Chinaka, 2016). That involves all behaviors that individuals showcase from searching, using, examining, and disposing goods and services to fulfill their needs and wants. Consumer behavior reveals what consumer's needs and wants are, how they think, feel and choose products and services.

Gillani (2016) mentions that both internal and external factors influence consumer behavior. The consumer's environment includes friends, social norms, peers, religious groups, and role models (Reza, Asghar, 2013). External factors refer to friends, opinion Figures, family members, and celebrities (Babin, B. J \& Harris, 2020).

\section{Expert as a Reference Group}

Reference groups are social groups to which a consumer belongs and influence them (Chinaka, 2016). They help to form a person's attitude or behavior. They provide some points of comparison, choice alternatives, desires, and habits. Reference groups influence an individual's image, which affects purchasing behavior (Chinaka, 2016).

The figure's opinion usually influences the type of item a person will give. Opinion figures are a group source of approval before consumers purchase (Foong \& Yazdanifard, 2014).

The terms group and reference group need to be precise (Engel et al., 2012). A group is two or more individuals who share a set of norms, values, or beliefs and have certain implicitly or explicitly defined relationships to one another such that their behaviors are interdependent. A reference group is a group whose presumed an individual uses perspectives or values as the basis for their current behavior.

Schiffman \& Kanuk (2004) stated that marketing communication through advertising in various mass media often uses reference groups. The reference groups are celebrities, experts, ordinary people, peers, parents, company executives or employees, and trade characters or spokespersons. These reference groups can influence the brand selection, buying interest, and consumption of certain goods or services.

Expert is anyone who possesses unique information or skills that can help consumers make better purchase decisions (Engel et al., 2012). Expert as someone who, because of his job, special training, or experience, is unique to help potential customers evaluate a product or service (Schiffman \& Kanuk, 2004). Companies often use widely recognized experts to advertise their relevant products. Experts are expected to support the development and explain why the product is good (Peter \& Olson., 2002). In KBBI (Kamus Besar Bahasa Indonesia) expert is people who are proficient, fully understand in a science (intelligence); proficient.

Religion leaders are also known as an expert, people who study religion and divinity; pious. Muthohar \& Triatmaja (2013) said that companies currently use religious figures, preachers, or more people call da'i/ustad/ustadzah (Islamic preachers) as alternative endorsers for their products. The presence of ulama endorsers in advertisements, especially on television, is a relatively new phenomenon. And quite interesting to note and research further. This cannot be separated from the existing fact that the majority of Indonesia's population is Muslim, which is considered a gap and an excellent opportunity for marketers and ad designers to create ads that have a solid appeal to consumers from this religious segment.

\section{RESEARCH METHODOLOGY}

Hypothesis:

Religious figures significantly influence adult's halal cosmetic buying behavior

Participants consisted of 200 women aged 20-40 years and who used halal cosmetics. The sampling technique is purposive sampling. Collecting data using a questionnaire developed by researchers based on Martin, A. K. \& Alan (2000). The questionnaire uses a four-point Likert Scale, from one to four points. From strongly agree to disagree strongly, which is used to measure the influence of the reference group and purchase behavior. Examples 
of items such as Religious Figures influence me to buy halal cosmetic products; I will purchase the halal cosmetic product - data analysis using simple regression.

\section{Respondent Characteristic}

The majority of the subjects in this study were aged 20 - 25 years, as many as 167 people (83.5\%), age 26 30 years as many as 20 people (10\%), aged $31-40$ years 12 people (6\%). For more detail can be seen in the table below.

Table 1. Respondent Characteristic

\begin{tabular}{ccc}
\hline Age (years old) & Frequency & Percentage \\
\hline $20-25$ & 167 & 83.5 \\
$26-30$ & 20 & 10 \\
$31-40$ & 13 & 6.5
\end{tabular}

Before the data is tested, use regression, it is necessary to test the validity and reliability using Cronbach Alpha. The results show that Cronbach alpha value of 0.872 with the validity value of all items above 0.2 . It means that the things in the religious figures' influence are valid and reliable.

\section{Regression}

Data analysis for religious figures influence, shown that $r=0.421$ and $\operatorname{sig}(p)=0.000 ; p<0.05$. There is a significant effect of the religious figures' influence on buying behavior in halal cosmetic products. The value of $r=$ $0.421, \mathrm{R}^{2}=0.177$ show that religious figures influence is $17.7 \%$, while the remaining $82.3 \%$ is influenced by other factors. For more details, see table 2 below.

Table 2. Detail analysis

\begin{tabular}{ccccc}
\hline $\mathrm{R}$ & $\mathrm{R}$ Square & Adjusted R Square & Std. An error of the Estimate \\
\hline .421 & .177 & .173 & .981 \\
\hline
\end{tabular}

\section{RESULTS AND DISCUSSION}

With the increase in spirituality/religiosity has come an increase in the sales of product-related to religion, including Halal Cosmetic.

Religious figures also have a significant influence on the behavior of buying halal cosmetics. It may be because the consumption/use of halal products is part of a religious order. (Engel et al., 2012) said that religious groups (also religious figures) could sometimes affect consumer behavior. Religious figures/ figures are seen as someone who has good spiritual knowledge even more than people in general. Indonesian consumers are still religious consumers, even though many secular movements have sprung up in the world. This spiritual nature can still survive because the religiosity of Indonesian consumers can keep up with the developments of the modern world today (12 Karakter Unik Konsumen Indonesia., 2016).

Indonesian consumers are increasingly paying attention to religious issues, and they also tend to be stronger. The market shares of products that have religious values will be even more outstanding. Indonesian consumers will be more sensitive to their religion and beliefs. Islamic banks will be more advanced. Products such as books, music, food, telecommunications, and even media that carry religious messages will increasingly have the opportunity to develop (12 Karakter Unik Konsumen Indonesia., 2016). Therefore, it is not surprising that religious figures also play a significant role in buying halal products, in this case, halal cosmetics. The influence of religious figures is 17.7\%. This condition follows the findings of Zhang, Y.\& Neelankavil, 1997), which states that the characteristics of the social and cultural values of the target group can limit the choice of advertising themes used in a particular culture. In other words, the target audience's advertising theme to be more readily accepted must be adjusted to the values, norms, culture, and religion of the target audience.

Compared with a previous study, "The Influence of Islamic Preacher toward the Attitude and Consumers Purchase Intention" (Muthohar \& Triatmaja, 2013). This study intends to explain the effect of using ulama endorsers in advertising on consumers' attitudes and buying interest and determine the main variables that affect consumer attitudes and purchase interest. The analysis results say that the ulama endorser's characteristics proved to have a significant simultaneous and partial effect on attitudes and consumer buying interest.

The results of Kholik's research (2017) on 78 students in the Assyafiiyah dormitory in Peterongan Jombang found that the charismatic leadership variable had a significant effect on student decisions, indicated by the results of the determination coefficient test of 0.594 or equivalent to $59.4 \%$. Voting behavior is part of consumer buying behavior.

\section{CONCLUSION}

Religious figures have a significant influence on the adult's purchasing halal cosmetic products in adult $s$. Based on the regression test, there is a significant effect of the religious figures influenced the behavior of buying halal cosmetic products, $17.7 \%$, while other factors influence the remaining $82.3 \%$.

By looking at the significant influence of religious figures, it's essential for marketing managers to consider 
and try to build awareness and gain support or partnering, to involve them in promotion or marketing communications (whether in below the line or above the line strategic). But marketers must be careful in choosing the correct religious figures. Even though Indonesia is a religious nation, not automatically all products related to religion or religious figures will succeed.

\section{REFERENCES}

12 Karakter Unik Konsumen Indonesia. (2016, Oktober 14). MARKETING.co.id.https://marketing.co.id/12-karakterunik-konsumen-indonesia/

Ali, S., Halim, F., \& Ahmad, N. (2016). The State of Halal Cosmetic Research on Consumer Behavior: A Systematic Review of the Literature and Future Research Directions. JEL Classification, 40-51.

Awantary, D. M. 2014. Pengaruh pencantuman label halal terhadap keputusan pembelian kopi "Luwak White Koffie" pada mahasiswa Fakultas Syari'ah dan Fakultas Ekonomi dan Bisnis Islam (FEBI).Skripsi : IAIN Walisongo Semarang. Diakses dari : https://eprints.walisongo.ac.id/id/eprint/3611

Babin, B. J \& Harris, E. (2020). Consumer Behavior. Cengage Learning Asia.

Chinaka, D. E. (2016). Factors That Influence Consumer Purchasing Behavior in Nigeria. The International Journal Of Business \& Management. $4 \quad$ (4). $\quad 157 \quad$ - $161 . \quad 10$ Retrieved from http://internationaljournalcorner.com/index.php/theijbm/article/view/126317

Eliasi JR, Dwyer JT. Kosher and Halal: religious observances affecting dietary intakes. J Am Diet Assoc. 2002 Jul;102(7):911-3. doi: 10.1016/s0002-8223(02)90203-8. PMID: 12146548.

Engel, James F; Blackwell, Roger D; Winiard, Paul W; Budijanto, F.X. (1994). Perilaku konsumen / James F. Engel, Roger D. Blackwell, Paul W. Miniard ; alih bahasa, Budijanto. Jakarta :: Binarupa Aksara.

Escalas, Jennifer \& Bettman, James. (2015). Managing Brand Meaning through Celebrity Endorsement. Review of Marketing Research. 12. 29-52. 10.1108/S1548-643520150000012002.

Foong, L. S., \& Yazdanifard, R. (2014). Celebrity Endorsement as a Marketing Tool. Global Journal Of Management And Business Research: E-Marketing, http://journalofbusiness.org/index.php/GJMBR/article/viewFile/1429/1336

Gillani, F. (2012). Impact of Peer Pressure and Store Atmosphere on Purchase Intention: An Empirical Study on the Youngsters in Pakistan.

Ireland, John \& Rajabzadeh, S. (2011). UAE consumer concerns about halal products. Journal of Islamic Marketing., 2, 274-283.

Kholik, A. (2017). Pengaruh Kepemimpinan Kharismatik Kyai Terhadap Keputusan Santri Dalam Memilih Asrama AS-SYAFI ${ }^{e}$ IYAH Di Pondok Pesantren DARUL ULUM Jombang. Tesis : Universitas Pesantren Tinggi Darul Ulum.

Kotler, P., \& Armstrong, G. (2016). Principles of Marketing 16th Edition: Global Edition. England: Pearson Education Limited

Martin, C.A., \& Bush, A.J. (2000). Do role models influence teenagers' purchase intentions and behavior? Journal of Consumer Marketing, 17, 441-453.

Muthohar, M., \& Triatmaja, A. R. (2013). Pengaruh Endorser Ulama terhadap Sikap dan Minat Beli Konsumen. Jurnal Bisnis Dan Ekonomi (JBE), 19(1), 86-99. https://www.unisbank.ac.id/ojs/index.php/fe3/article/view/2348

Peter, J. P., \& Olson., J. C. (2002). Consumer Behavior and Marketing. Strategy Sixth Edition. McGraw-Hill Irwin.

Reza, Asghar, S. \& V. S. (2013). Influence of Social Reference Group on Automobile Buying Decision-Research on Young Executives. World Review Business Research, 3(4), 197-210.

Sangaji. (2013). Perilaku Konsumen. CV. Andi Offset.

Schiffman, L. G., Kanuk, L. L., \& Hansen, H. (2012). Consumer Behavior a European Outlook Second Edition. Pearson.

Schiffman, L., \& Kanuk, L. (2004). Consumer behavior, 8th International edition. Prentice-Hall.

Setiadi, N. (2015). Perilaku Konsumen: Perspektif Kontemporer pada Motif, Tujuan, dan Keinginan Konsumen,. Kencana Prenada Media.

Suki, M., Norazah, \& Sulaiman, A. (2016). Does Halal image strengthen consumer intention to patronize Halal stores? Journal of Islamic Marketing, 7, 120-132.

Zhang, Y.\&Neelankavil, J. P. (1997). The Influence of Culture on Advertising Effectiveness In China and The USA: A Cross-Cultural Study. European Journal of Marketing, 31. 